\title{
VILLAGE FUND MANAGEMENT IN THE PERSPECTIVE OF STATE FINANCES FOR THE PURPOSE OF RURAL COMMUNITY EMPOWERMENT
}

\author{
${ }^{1}$ Sri Winarsi \\ Administrative Law Department \\ Faculty of Law, Universitas Airlangga, \\ Surabaya, Indonesia \\ sriwinarsi_fhunair@yahoo.com
}

\author{
${ }^{2}$ Dwi Rahayu Kristianti \\ Constitutional Law Department \\ Faculty of Law, Universitas Airlangga, \\ Surabaya, Indonesia \\ dwi.rahayu@fh.unair.ac.id
}

\begin{abstract}
Law No. 6 of 2014 on Villages provides a legitimate basis for the position of the village as an autonomous entity within the framework of the Unitary State of the Republic of Indonesia. It has amended Government Regulation Number 72 of 2005 on Village. One of the major changes related to the autonomy of Village Financial Management which must follow the procedures as stipulated in the legislation. Law No. 6 of 2014 on Villages stipulates village financial resources which are village original revenues, allocations of State Budget, part of local tax and Regency / City retributions, allocation of village funds that are part of balance fund received by Regency / City, financial assistance from the Provincial Budgets and Regency / City Budgets, non-binding grants and donations from third parties, and other legitimate village revenues. The existence of various sources of village finance is very closely related to the financial system of the State, resulting in legal issues related to the model of financial decentralization applied to the village, the procedure of allocating revenues and expenditures, legal status and accountability of the Village Head as the recipient of revenue allocation. This research is normative law research through library research. This study was conducted by studying the conceptual approach of village financial management that requires the support of empirical data. It then combines the basic concepts with statute approaches and the implementation of budgeting activities for the use of village funds in village government. These steps are expected to answer the research problems and realize the purpose of this study.
\end{abstract}

Keywords-Villages; Village Funds; Decentralized Finances.

\section{INTRODUCTION}

As mandated by Law No. 23 of 2014 on Local Government, the Regions have the authority to make policies on villages, especially in providing services, increasing participation, and enhancing community empowerment initiatives aimed at community welfare. In New Order era, the regulation on village was legislated by the Law No. 5 of 1979 on Village Government. Along with the development of state administration in Indonesia, President Susilo Bambang Yudhoyono within Reformation Order passed the Government Regulation No. 72 of 2005 on Village. This revokes the
Government Regulation No. 76 of 2001 on General Guidelines on Village Management, which also introduces new things on village management. The enactment of the Government Regulation No. 72 of 2005 does not revoke the Law No. 5 of 1979 , hence this law is still enforced.

The Law No. 5 of 1979 and the Government Regulation No. 72 of 2005 state that the village is an entity that has original autonomy, meaning that the village has the right to regulate and manage its own territory. Given the importance of the village as part of the Unitary State of the Republic of Indonesia and to achieve the goal of improving the welfare of rural communities, the Government passes Law No. 6 of 2014 on Villages.

The enactment of the Law No. 6 of 2014 gives a great opportunity for villages to manage their own governance and development, also to improve the welfare and life quality of rural communities. In addition, it is expected that the village government to be more independent in managing the government and various natural resources owned, including the financial management and wealth of the village property. This big role comes with big responsibility for the village government. Therefore, the village government should be able to apply the principle of accountability in its governance, where all of village administration activities must be accountable to the village community in accordance with the provisions.

Law No. 6 of 2014 on Villages stipulates that they have a source of income namely village original revenues, profit sharing from local tax and Regency / City retributions, part of central and local balance fund received by District / City, allocations from State Budget, financial assistance from Provincial Budget and District / City Budget, and non-binding grants and donations from third parties.

The Village revenue is used to fund all of the authorities which are the responsibility of the Village. The funds are used to finance the implementation of village authority covering governance, development, community 
empowerment, and social affairs. Thus, village revenues sourced from the State Budget are also used to finance these authorities.

In 2015, the Corruption Eradication Commission (KPK) found 14 potential problems in the management of village funds amounting to Rp. 20.7 trillion in the Revised State Budget 2015. The funds was planned to be channeled to 74,093 villages throughout Indonesia. One of the reasons is the aspect of institutional regulation consisting of incomplete regulations and technical guidelines for village financial implementation, the potential for overlapping authority between the Ministry of Village and the Directorate General of Village Government Development within the Ministry of Home Affairs, non-transparency formula of village funds distribution in Government Regulation No. 22 of 2015 which based on the equity only. Additionally, the distribution arrangements of fixed income for village apparatuses from the village budget set forth in Government Regulation No. 43 of 2014 are deemed to be less fair and the inefficient obligation to perform accountability reports by villages due to poor and overlapping regulatory provisions. The most striking issue is the changed formula of village funds distribution. As an illustration, according to the formula set forth in the Government Regulation No. 60 of 2014, Village A with area of 7.5 square $\mathrm{km}$ and has 21 hamlets will get village funds Rp437 million, while Village B with an area of 1, 5 square km and has 3 hamlets then get funds Rp41 million. However, with the new regulation within the Government Regulation No. 22 of 2015 Village A can get Rp312 million and Village B Rp263 million. [1]

There are five problems found in terms of implementation: the time frame of the village budget management site is difficult to be obeyed by the villages, the unavailability of unit price of goods or services used as a reference for the village in preparing the village budget, the low transparency of the village budget usage plan and accountability. In addition, accountability reports made by the village have not followed the standard and are prone to manipulation. Furthermore, the existed village budget is not fully described the needs of the village. Meanwhile, in the supervision aspect there are three potential problems faced, namely the low effectiveness of the local inspectorate in the village financial management monitoring, public complaints poor management by all regions, and unclear evaluation scope of supervision by the sub-district. Moreover, within human resources aspect there is a prospective problem that the village counselor potentially corrupt by exploiting the weakness of village apparatuses.

There are also some real and contextual issues in relation to the village funds management. First, the village does not have a knowledge on village-owned enterprise. Some consider this as a new creature whose gender is unclear. Second, the capacity of the village apparatus in developing and optimizing the village potential utilization is not well distributed. Currently, there are only about 1000 villageowned enterprise running, and there are still about 73,093 other villages that do not have village-owned enterprise yet.
Third, local governments have a low commitment to the village. The function of Regency / City to facilitate and develop villages still not yet run in all regions. Fourth, the central government sometimes simplifies the problem to the extent of village funds, resulting in uncertainty in the field, especially in relation to the village fund position in the Village Budget. Fifth, in about 32,000 villages there are fatal administrative constraints, especially related to the technocratic capabilities of the village. In the case of financial reports for example, there is a high dependency from village to higher institution. Such a series of issues should be an important note to revise government policy, especially to reduce distortions in the village. Nevertheless, he said, it should be proud that at this moment the surge to build has begun to grow and develop in the village. [2] Therefore this article will analyze the "Village Fund Management in The Perspective of State Finances for The Purpose of Rural Community Empowerment”.

\section{RESEARCH METHODS}

This research is a legal research, which can provide input on regulation, management, and utilization of local asset land in local governance. The approach used is a statute approach that focuses on the prevailing rules as an attempt to analyze hierarchical relationships, consistency and conformity between local asset management rules and other laws and regulations. This study also uses a conceptual approach by reviewing and analyzing the concepts and theories about local governance, local government assets associated to financial management of village funds in order to prosper the community. In addition, this research is also conducted by case study approach that is analyzing and reviewing cases related to the issues discussed. Analysis is done qualitatively, both by presenting legal principles (such as legal principles of legislation) and its legal requirements (mechanism) as well as analyzing various social, economic and political factors in the process of influencing the procedural and substantive cases settlement of local government land.

\section{DISCUSSION}

Law No. 33 of 2004 on Financial Balance between the Central Government and the Local Government affirms that the whole local spending is prioritized to protect and to improve the quality of community life in an effort to fulfill local government obligations. In order to improve the service and welfare of the community, the village has the right to obtain a share of central and local financial balances received by the Regency.

The acquisition of the village finance portion of the Regency is the Village Fund Allocation, which is channeled through Village Cash / Village Account. Provision of Village Fund Allocation is a fulfillment of the village right to establish its autonomy in order to grow and develop in line to the growth of the village itself based on diversity, participation, original autonomy, democracy and community empowerment. Through this Village Fund Allocation, the Local Government seeks to revive the values of the village community's 
independence by building full trust in the community to manage and build their own villages.

The village fund management is actually regulated in Government Regulation No. 60 of 2014 on Village Funds Sourced from the State Budget as amended by Government Regulation No. 22 of 2015. Government Regulation No. 60 of 2014 on Village Funds Sourced from the State Budget in its development needs to be adjusted to the development of law and governance, hence it is necessary to amend some provisions of the articles contained in the Government Regulation. Amendments to Government Regulation No. 60 of 2014 on Village Funds Sourced from the State Budget, among others, are intended to increase the budget of the Village Fund as the budget of the Village Fund allocated in the State Budget of Fiscal Year 2015 still has not reached 10\% (ten percent) of the Transfer Fund to the local government as mandated by Law No. 6 of 2014 on Villages. In addition, the change of the Village Fund allocation formula is also intended to ensure that there is no high gap among villages on the amount of Village Funds that will be received by each village so that it becomes more equitable and fair.

\section{A. Good Governance Principles in Budgeting and Use of Village Funds}

The problems experienced today by Indonesia highly increase, becoming complex and more laden. Some of government apparatuses who should be role models of the people stumbled over legal issues. The existence of good governance that has been hailed is still a mere jargon nowadays. The implementation of a good governance should be a serious concern. Transparency can indeed be one solution but not enough to achieve a good governance.

The term good governance was born since the end of the New Order which was replaced by a reform movement. Since then, the good governance is also often raised as a discourse or main theme in every governmental activity. However, the law on good governance has not been regulated specifically in the form of a legal product, such as the Act for example. There is only one regulation, namely Law No. 28 of 1999 on the Clean and Free State Administration from Corruption, Collusion, and Nepotism which governs the administration of the state with the General Principles of Good Governance.

The meaning of governance and good governance is basically not regulated in a law. However, it can be interpreted that governance is state administration or management. It means that power is no longer solely owned or become government affairs. Governance itself has a verb element that means the function of government together with other agencies (NGOs, private and citizens) are carried out in a balanced and participatory. While good governance means running the good, clean and authoritative government functions. [3]

The village refers to the area inhabited by the community, in which there are sources of production and also has governance, is bound by the rules agreed by the community and there are arrangements to enforce the rules, so that it can be called government. In this context, the village was a country. When the state is still in the form of a monarchy or is now beginning to shift into a unitary state that integrates the various regions, the village already exists. Therefore, the village, since its inception is an autonomous region. [4]

The essence of village development aims to improve the condition and rural standard of living. Additionally, the village government is a development strategy that allows equitable distribution of development; the results enjoyed by the people; high economic growth; and achievement of dynamic regional security stability. Village government as a means to achieve the purpose of state administration, serves as an extended government within the framework of national development for the achievement of equitable prosperity of the people. [5]

The discussion on village development is closely related to the village funds. The village funds sourced from the State Budget allocated for the villages transferred through the Regency / City budget is used to finance the organizer and rural community empowerment (Article 1 point 8 of Government Regulation No. 43 of 2014 on the Implementation of Law No. 6 of 2014 on Villages). The scope of village financial management includes planning, implementation, monitoring, and accountability of village finances. Village finances are reflected in the Village Budget. In the management of village funds often the problems faced are effectiveness and efficiency, priorities, leaks and irregularities as well as low professionalism. Good financial management has a significant effect on village governance.

It can be seen at the current Indonesian State Budget that each village will receive more than Rp.1 billion. This provides a fresh air for village governance, but the problem is that with such huge funds in the village, it is feared to bring up the corrupt perpetrators at the village level if the village administration does not implement a good village governance. The role of village government in implementing good governance is the implementation of the village government's tasks, functions, authorities, rights, and responsibilities in the planning, implementation of village development, particularly those related to village governance.

Good governance has long been a dream for many people in Indonesia. Although the understanding of each person about good governance is different, but essentially through the implementation of good governance, it is expected that the quality of government will be improved for the better. Having better good governance practices will increase the quality of public services. It can be projected that the number of corruption decreases and the government becomes more concerned with the interests of the citizens.[6] Therefore it can be concluded that good governance can be a guarantee to: (a) minimize the occurrence of corruption; (b) represent the minority perspective; (c) pay attention to the views and opinions of the weakest in decision-making.

Good governance of village funds is an important and urgent thing to be applied. According to Article 72 of the Village Law, the amount received by the village will be greater. It happens because at least $10 \%$ of the Regency / City tax and levy must also be submitted to the village. The village funds must be properly budgeted. Otherwise, it can become a new state financial mismanagement. As the number of villages reaching more than 80,000 villages, the audit of village funds is one of the main challenges. Therefore, good governance 
principles need to be prepared from the beginning to reduce the village fund mismanagement.

The large number of village funds obtained from the central and local governments should be followed by accountability in every development or activity held in villages with the aim of the prosperity of the rural community. There are still many villagers who do not know every use of funds related to village funds. It makes them have less trust to their own village administration. Also, there is a lacking knowledge of some of the village apparatuses in reporting the finances of each activity to the Regency / City. This occurs because the village apparatuses have not been able to make financial reports that meet government accounting standards to support the implementation of good village governance. The adoption of the principles of good governance in the management of village finances will undoubtedly be able to realize the management of village finance that is free of corruption and collusion, effective and efficient.

The concept of good governance can be interpreted as a reference to the process and structure of good political and socio-economic relations. Human interest is the strongest factor that currently affects both bad and good governance. It is an integral part of life that every human being has interests, individual, groups, national and even international interests. There is always a collision in order to realize every interest. Likewise in realizing the good governance, the conflict of interest has always been a major obstacle. Interests give birth to distance and bulkheads between individuals and groups that make it difficult to achieve the word "agree".

Good governance is basically a concept that refers to the process of achieving its decisions. Its implementation can be accounted collectively, as a consensus reached by governments, citizens, and the private sector for the administration of governance within a country. The State has a role to provide services for the welfare of the people. This must be accompanied by a good justice system and a governmentally accountable system by referring to 3 (three) pillars of sustainable development in the context of economic development, environment and human development. Good governance facilitates 3 (three) parties namely the government (state organizer), the corporate or business (economic agent), and civil society to find the suitability. These three parties play a role and influence each other in the implementation of a good state. Synchronization and harmonization among parties is a key answer. However, it is difficult to be achieved in Indonesia nowadays.

In order to support the realization of good governance in village management, the governance principles is used in the village financial management. This consists of transparent, accountable, participative and is carried out in an orderly and disciplined budget. Additionally, the United National Development Program (UNDP) states that there are 14 principles within good governance, namely: (a)visionary; (b)openness and transparency; (c)participation; (d)accountability; (e)rule of law; (f)democracy; (g)profesionalism and competency; (h)responsiveness; (i)efficiency and effectiveness; (j)decentralization; (k) private Sector and civil society partnership; (1)commitment to reduce
Inequality; (m)commitment to environmental protection; (n)commitment to Fair Market.

\section{B. Legal Policy of Village Fund Management in the State Financial Framework}

Rural development is the entire development activities that take place in the countryside, covering all aspects of life of the entire community which is implemented in an integrated manner by developing self-help program. The success indicator of village development is basically a real improvement in the living conditions of society as a whole. As it is said that development is always a better process of improvement. These development needs are not limited to primary needs, basic services, environment and rural community empowerment activities.

The principle of local autonomy used is the principle of wide local autonomy in the sense that the districts are given the authority to administer and regulate all governmental affairs outside of which the Government affairs stipulated in the Law. Thus the content and type of autonomy for each district is not always the same as other districts. The definition of responsible autonomy is the implementation of autonomy must be completely in line with the purpose and goals of autonomy, which is basically to empower the district including improving people's welfare which is the main part of the national goal.

Along with that principle the implementation of local autonomy should always be oriented towards improving the welfare of the community by always paying attention to the interests and aspirations that grow in society. Therefore, it requires the local financial management system which is good, transparent and accountable. Based on this, the districts have the authority to administer village policies, especially in terms of providing services, increasing community participation and self-help, initiatives, innovation and rural community empowerment to realize the welfare of the community.

In this regard, to improve the capacity of Village Governments, the development and empowerment of rural communities needs a greater attention, such as through the allocation of village fund management or Village Fund Allocation. Village Fund Allocation is granted to the Village for the purpose of: (a) Improving the implementation of village governance in the implementation of government, development and community services in accordance to their authority; (b) Improving the capacity of Community Institutions in the village in participatory planning and development control in accordance to village potential; (c) Increasing equitable income, employment opportunities and opportunities for village communities; (d) Encouraging the improvement of self-help community.

As it is known that the source of income of the Village comes from the allocation of the State Budget. The village expenditure is prioritized to meet the development needs agreed upon in the Village Forum and in accordance with the priorities of the Regency / City Government and Provincial Government. 


\section{CONCLUSION}

Village funds are sourced from the State Budget that are intended for the village, which is transferred through the Regency / City Budget and used to finance the organization, and community empowerment (Article 1 point 8 of Government Regulation No. 43 of 2014 on the Implementation of Law Number 6 Year 2014 on the Village). The large amount of village funds can cause problems. It is feared that it will bring up the corruptors at the village level if good village governance does not implemented. In this case, good governance principles are needed in budgeting and the use of village funds. These include transparency, accountability and participation. However, the main obstacle to good governance in budgeting and the use of village funds is a conflict of interests that spawns distance and insulation between individuals and groups.

\section{References}

[1] Siwi Pramesti, KPK Temukan 14 Potensi Masalah Pengelolaan Dana Desa, 12 Juni 2015,http://nasional.sindonews.com/read/1012030/13/kpk-temukan14-potensi-masalah-pengelolaan-dana-desa-1434116438, diakses pada tanggal 30 Mei 2016

[2] Yustinus Paat, Pemerintah Diminta Atasi Masalah Pengelolaan Dana Desa, 03 April 2016, http://www.beritasatu.com/nasional/358154pemerintah-diminta-atasi-masalah-pengelolaan-dana-desa.html, diakses pada tanggal 30 Mei 2016

[3] Prasetijo, 2009, "Good Governance Dan Pembangunan Berkelanjutan", dalam http://prasetijo.wordpress.com, diakses pada tanggal 28 Mei 2017.

[4] Riswandha Imawan, "Desentralisasi, Demokratisasi, dan Pembentukan Good Governance”, Jurnal Otonomi Daerah, Vol. II (6), Juni 2003, h.56-60.

[5] Widjaja, 2002, Pemerintah Desa dan Administrasi Desa, Jakarta: PT. Raja Grafindo Persada, h.31.

[6] Agus Dwiyanto, 2005, Mewujudkan Good Governance Melalui Pelayanan Publik, Yogyakarta: Gajahmada University Press, h.20. 